\title{
Storage of Soybean Seeds and Addition of Insecticide and Micronutrients
}

\author{
Gustavo H. Demari ${ }^{1}$, Vinícius J. Szareski ${ }^{1}$, Ivan R. Carvalho ${ }^{1}$, Tuane A. da Silva ${ }^{1}$, Vânia M. Gehling ${ }^{1}$, \\ Danielli Olsen ${ }^{1}$, Tamires S. Martins ${ }^{1}$, Francine Lautenchleger ${ }^{2}$, Lucian A. dos Santos ${ }^{1}$, Luis O. B. Schuch ${ }^{1}$, \\ Geri E. Meneghello ${ }^{1}$, Velci Q. de Souza ${ }^{3}$, Tiago Pedó ${ }^{1}$, Francisco A. Vilella ${ }^{1} \&$ Tiago Z. Aumonde $^{1}$ \\ ${ }^{1}$ Federal University of Pelotas, Capão do Leão, RS, Brazil \\ ${ }^{2}$ State University of Londrina, Department of Plant Science, Londrina, PR, Brazil \\ ${ }^{3}$ Federal University of Pampa, São Gabriel, RS, Brazil \\ Correspondence: Ivan R. Carvalho, Federal University of Pelotas, Capão do Leão, RS, Brazil. Tel: \\ 55-99-640-8757. E-mail: carvalho.irc@gmail.com
}

Received: November 16, 2017

doi:10.5539/jas.v11n1p553
Accepted: October 8, $2018 \quad$ Online Published: December 15, 2018

URL: https://doi.org/10.5539/jas.v11n1p553

\begin{abstract}
The objective of this work was to evaluate the effects on the physiological attributes of soybean seeds submitted to the seed treatment with addition of insecticide, polymers and micronutrients throughout the storage. The experimental design was completely randomized in a factorial scheme, with four seed treatments per two seasons of storage of the seeds. The analysis of variance revealed a significant interaction among seed treatments and storage times for both cultivars at $5 \%$ of probability, referring to the characteristics of shoot length (SL), primary root length (RL), shoot dry mass (SDM) and dry mass of the primary root (RDM) for the cultivar Fundacep 37 RR. Addition of seed treatments influences the physiological performance of seedlings originated from soybean seeds stored for 240 days. The shoot and primary root lenghts, and shoot dry mass express the isoenzyme esterase through the aerial part and primary root of the seedling, the malate dehydrogenase is expressed in the primary root while in the peroxidase it is evident in the shoot of the seedlings.
\end{abstract}

Keywords: soybean, physiological potention, maneagent crops

\section{Introduction}

The soybean (Glycine $\max$ (L.) Merrill) belongs to the Fabaceae family being characterized as one of the main oleaginous plants produced worldwide, due to its economic importance and nutritional quality coupled with high crude protein concentration (Follmann et al., 2014). In Brazil, it is evidenced as the most cultivated species in the most varied agricultural regions, which provided an increase of $12.18 \%$ in national production for the 2016/2017 crop season (Conab, 2017).

These increases are due to the technological advances and seed quality used that directly influence the performance and establishment of the plants in the field (Ferrari et al., 2014; Meira et al., 2016). However, before the seeds are used in the field, they are submitted to certain periods of storage where some peculiar situations the seeds have been treated and exposed to stresses, that will contribute to reduce or maintain the physiological quality of the seeds. Among these treatments, the use of insecticides conjugated to polymers, fungicides and micronutrients (Pereira et al., 2005; Karam et al., 2007; Carvalho et al., 2015; Zanatta et al., 2018) stands out.

The use of insecticides in the seed treatment in combination with polymers and micronutrients may increase seedling uniformity, change the field emergence, provide conditions for the seeds to express their maximum vigor (Follmann et al., 2014), on the other hand, some products used may compromise the emergence of seedlings (Souza et al., 2015; Szareski et al., 2015).

The use of insecticides in the seed treatment in combination with polymers and micronutrients may increase seedling uniformity, change the field emergence, provide conditions for the seeds to express their maximum vigor (Follmann et al., 2014), in contrast, some (Sauzar et al., 2005). In addition, the use of seedlings has been shown to increase the number of seedlings. In general, insecticides are used to control insect pests and exert bioactivities that benefit agronomic interest attributes as well as soybean yield (Pelegrin et al., 2016; Ferrari et al., 
2015). However, seeds treated and stored for up to 120 days may reflect positively on the dry matter accumulation of the seedling and on the leaf area (Ludwig et al., 2015), in contrast, storage prolongation may negatively affect the physiological quality of the seeds (Dan, et al., 2010, Souza et al., 2015; Gabriel et al., 2018).

There are certain cases that require longer storage periods of treated seeds, this may result in effects on physiological attributes such as seedling dry mass and activity while, the possibility of performing seed treatment in advance may facilitate the organizational logistics of the seed processing unit. In this context, the objective of this work was to evaluate the effects on the physiological attributes of soybean seeds submitted to the seed treatment with addition of insecticide, polymers and micronutrients throughout the storage.

\section{Material and Methods}

The work was conducted at the Seed Analysis Laboratory of the Postgraduate Program in Seed Science and Technology of the Eliseu Maciel Agronomy College, Federal University of Pelotas, located in the municipality of Capão do Leão, RS, Brazil. The soybean seeds used came from the cultivars Fepagro 37 RR and Nidera 6411 $\mathrm{RR}$, which obtained initial germination of 81 and $82 \%$. The treatments used were:

$T_{1}$ : seeds without treatment;

$T_{2}$ : seeds treated with micronutrients $\left(2 \mathrm{~mL} \mathrm{~kg}^{-1}\right.$ of commercial product based on $6.7 \%$ copper, $3.2 \%$ molybdenum, $15 \%$ zinc and 9.4\% manganese) + insecticide (thiametoxam at the dose of $350 \mathrm{~g} \mathrm{~L} \mathrm{~kg}^{-1}$ of seeds) + polymer $\left(0.5 \mathrm{~mL} \mathrm{~kg}^{-1}\right.$ of seeds);

$T_{3}$ : seeds treated with insecticide (Thiametoxam at a dose of $350 \mathrm{~g} \mathrm{~L} \mathrm{~kg}^{-1}$ of seeds) + polymer $\left(0.5 \mathrm{~mL} \mathrm{~kg}^{-1}\right.$ of seeds);

$T_{4}$ : seeds treated with micronutrients $\left(2 \mathrm{~mL} \mathrm{~kg}^{-1}\right.$ of commercial product based on $6.7 \%$ copper, $3.2 \%$ molybdenum, $15 \%$ zinc and $9.4 \%$ manganese $)+$ polymer $\left(0.5 \mathrm{~mL} \mathrm{~kg}^{-1}\right.$ of seeds $)$.

Seeds were treated using a spray volume of $6 \mathrm{ml} \mathrm{kg}^{-1}$ of seeds using commercial concentrations of each isolated formulation, the seeds were distributed in individual plastic bags for each treatment. After the homogenization the seeds were transferred to paper bags and kept at room temperature for 24 hours, the rest of the seeds were stored in paper bags under controlled conditions of medium air temperature $\left(15^{\circ} \mathrm{C}\right)$ and relative humidity $(50 \%)$ for 360 days.

The primary root and aerial part lengths of the seedlings, dry mass of the primary root and aerial part of the seedlings, expression of the isoenzymes: esterase, glutamate oxaloacetate transaminase, malatodesidrogenase, and peroxidase were measured, being these measured 240 days after the treatment of the seeds, to obtain the characters of interest the following methodologies were followed:

The length of the primary root and aerial part of the seedlings were obtained by the measurement of 10 seedlings at the end of the germination test, where the length between the basal insertion of the primary root to the apex of the shoot was measured, while the primary root length was measured between the apical distance and radicle base, results expressed in millimeters $(\mathrm{mm})$. Dry matter of the primary root and aerial part were obtained by measuring 10 seedlings at the end of the germination test, where the seedlings were conditioned in brown paper envelopes and subjected to drying in forced ventilation oven at $70{ }^{\circ} \mathrm{C}$ until constant mass, results expressed in milligrams (mg).

The determination of the isoenzymes was performed by measuring 10 seedlings at the end of the germination test at 8 days after sowing (Brasil, 2009). The expression of the isoenzymes: esterase, glutamate oxaloacetate transaminase, malatodesidrogenase and peroxidase were obtained by vertical electrophoresis in polyacrylamide gel (Malone et al., 2007). The seedlings were separately macerated in porcelain gral and kept in an ice bath, 200 $\mathrm{mg}$ of the macerate from each sample were transferred to microcentrifuge tubes and added with extraction solution (0.2M Lithium Borate at $\mathrm{pH} 8.3+$ Tris Citrate $+0.2 \mathrm{M}$ at $\mathrm{pH} 8.3+0.15 \%$ of 2-mercaptoethanol) in the ratio $1: 2(\mathrm{~m} / \mathrm{v})$.

Electrophoresis was performed on $7 \%$ polyacrylamide gels, applying $20 \mu \mathrm{L}$ of each sample, and the staining systems used are described by Scandálios (1969) and Alfenas (1998). The interpretation of the results of the isoenzymes was based on the visual analysis of the electrophoresis gels, where the presence or absence, as well as the intensity of each of the electrophoretic bands for each measured isoenzymatic system was considered.

The experimental design was completely randomized in a factorial scheme, with four seed treatments $\mathrm{x}$ two seasons of storage of the seeds. The effects were performed for each soybean cultivar separately and the treatments were arranged in four replicates. The data were submitted to analysis of variance where the 
interaction among seed treatments and storage times (zero and 12 months) at of 5\% probability was verified, the characters that showed interaction were dismembered to the simple effects, on the other hand, those that did not show interaction were dismembered to the main effects for each factor separately using the complementary analyzes by the Tukey test at 5\% of probability.

\section{Results and Discussion}

The analysis of variance revealed a significant interaction among seed treatments and storage times for both cultivars at $5 \%$ of probability, referring to the characteristics of shoot length (SL), primary root length (RL), shoot dry mass (SDM) and dry mass of the primary root (MR) for the cultivar Fundacep 37 RR. The initial growth of the soybean seedlings before storage (Zero) presented different results compared to the treatments of seeds tested for both soybean cultivars (Table 1), being proved by the performance of the characters length (SL) and shoot dry mass accumulation (SDM).

The primary root lenght (RL) showed superiority through the use of Thiametoxam and polymer referring to Fepagro 37 RR cultivar, this insecticide may have stimulated the initial growth of these seedlings (Almeida et al., 2012; Kavalco et al., 2015). In contrast, NS6411 RR showed better performance through the absence of seed treatments and the use of polymer and micronutrients (Table 1), where it obtained superiority for radicular length, in this context, the use of micronutrients and polymers with the seeds of soybean can maintain and even contribute to the enhancement of the physiological quality of soybean seeds (Bays et al., 2007). For both cultivars there was a decrease in the primary root lenght in the period after storage (12 months), these results corroborate with Dan et al. (2010) where they determined that the seed treatment reduces the length of seedlings after prolonged storage.

The shoot length (CPA) was superior for seedlings from seeds treated with Thimetoxan + micronutrients + polymers referring to cultivar Fepagro 37 RR, in contrast, the cultivar NS6411 RR was superior when the seeds were treated with micronutrients + polymers (Table 1). The differential performance between the cultivars is due to the metabolic responses intrinsic to the genetic and morphological constitution, as well as the contact surface of the plasma membranes that allow to increase or decrease the effects of the treatment on the seeds (Moterle et al., 2011; Szareski et al., 2016c).

Table 1. Influence of seed treatments and storage times on primary root (RL) ands hootlenghts (SL) of seedlings from soybean seeds (Fepagro37 RR (F.37) and NS6411RR (NS6411))

\begin{tabular}{|c|c|c|c|c|c|c|c|c|}
\hline \multirow{3}{*}{ Treatments } & \multicolumn{2}{|c|}{ F.37 } & \multicolumn{2}{|c|}{ NS.6411 } & \multicolumn{2}{|c|}{ F.37 } & \multicolumn{2}{|c|}{ NS.6411 } \\
\hline & Zero & 12 months & Zero & 12 months & Zero & 12 months & Zero & 12 months \\
\hline & \multicolumn{4}{|c|}{ RL $(\mathbf{m m})$} & \multicolumn{4}{|c|}{ SL (mm) } \\
\hline NoTreat. & $89.55 \mathrm{cA}^{*}$ & $90.75 \mathrm{aA}$ & $103.03 \mathrm{aA}$ & $54.50 \mathrm{aB}$ & $101.28 \mathrm{bA}$ & $109.12 \mathrm{aA}$ & $85.88 \mathrm{bA}$ & $63.50 \mathrm{aB}$ \\
\hline $\mathrm{M}+\mathrm{T}+\mathrm{P}$ & $98.30 \mathrm{bA}$ & $84.67 \mathrm{abB}$ & $86.08 \mathrm{cA}$ & $66.83 \mathrm{aB}$ & $109.10 \mathrm{aA}$ & $111.83 \mathrm{aA}$ & $80.50 \mathrm{bA}$ & $77.58 \mathrm{aB}$ \\
\hline $\mathrm{T}+\mathrm{P}$ & $103.48 \mathrm{aA}$ & $63.86 \mathrm{bB}$ & $95.15 \mathrm{bA}$ & $66.98 \mathrm{aB}$ & $103.88 \mathrm{abA}$ & $90.08 \mathrm{bB}$ & $83.38 \mathrm{bA}$ & $63.67 \mathrm{aB}$ \\
\hline $\mathrm{M}+\mathrm{P}$ & $97.15 \mathrm{bA}$ & $85.67 \mathrm{aA}$ & $101.50 \mathrm{aA}$ & $63.67 \mathrm{aB}$ & $99.00 \mathrm{bA}$ & $107.92 \mathrm{aA}$ & $101.08 \mathrm{aA}$ & $72.83 \mathrm{aB}$ \\
\hline $\mathrm{CV}$ & 5.90 & & 7.90 & & 3.10 & & 7.50 & \\
\hline
\end{tabular}

Note. * Means followed by the same letter, lower case in the column and upper case in the row, do not statistically differ for Tukey with $5 \%$ of probability.

After the seed storage, the shoot (SL) and primary root lenght (RL) with the use of Thimetoxan + polymer showed inferiority to the other treatments for the cultivar Fepagro 37 RR, in contrast, the shoot length (SL) of cultivar NS6411 RR (Table 1) reduced its magnitude after storage. In this way, the use of insecticides (Dan et al., 2010; Piccinin et al., 2013; Szareski et al., 2016a), polymers (Avelar et al., 2011) with seed treatment that will be maintained for a long period may negatively influence the physiological potential of soybeans.

The dry mass of the primary root (MR) and shoot (SDM) did not differ faced to the seed treatments (Table 2) used for both cultivars under conditions of absence of storage (Zero). Research has shown that the use of insecticide and bioregulator does not result in accumulation of dry matter in the seedlings (Dan et al., 2012; Moterle et al., 2011; Zimmer et al., 2016). However, the cultivar Fepagro 37 RR reduced the dry mass of the primary root after storage of the seeds. 
Table 2. Influence of seed treatments and storage times on dry mass of the primary root (RDM) and shoot dry mass (SDM) of the seedlings from soybean seeds (Fepagro37 RR (F.37) and NS6411 RR (NS6411))

\begin{tabular}{|c|c|c|c|c|c|c|c|c|}
\hline \multirow{3}{*}{ Treatment } & \multicolumn{2}{|c|}{ F.37 } & \multicolumn{2}{|c|}{ NS.6411 } & \multicolumn{2}{|c|}{ F.37 } & \multicolumn{2}{|c|}{ NS.6411 } \\
\hline & Zero & 12 months & Zero & 12 months & Zero & 12 months & Zero & 12 months \\
\hline & \multicolumn{4}{|c|}{ RDM (mg) } & \multicolumn{4}{|c|}{ SDM (mg) } \\
\hline NoTreat. & $25.54 \mathrm{aA} *$ & $21.66 \mathrm{aB}$ & 27.98 & 26.93 & $11.08 \mathrm{aB}$ & $45.55 \mathrm{aA}$ & $15.54 \mathrm{aB}$ & $46.60 \mathrm{aA}$ \\
\hline $\mathrm{M}+\mathrm{T}+\mathrm{P}$ & $24.60 \mathrm{aA}$ & $21.70 \mathrm{aB}$ & 28.41 & 27.44 & $11.05 \mathrm{aB}$ & $40.58 \mathrm{cA}$ & $14.62 \mathrm{aB}$ & $42.94 \mathrm{aA}$ \\
\hline $\mathrm{T}+\mathrm{P}$ & $24.65 \mathrm{aA}$ & $21.42 \mathrm{aB}$ & 29.02 & 28.62 & $11.58 \mathrm{aB}$ & $44.37 \mathrm{abA}$ & $14.30 \mathrm{aB}$ & $41.06 \mathrm{aA}$ \\
\hline $\mathrm{M}+\mathrm{P}$ & $24.50 \mathrm{aA}$ & $22.99 \mathrm{aB}$ & 29.77 & 30.39 & $10.77 \mathrm{aB}$ & $43.23 \mathrm{bA}$ & $16.11 \mathrm{aB}$ & $44.04 \mathrm{aA}$ \\
\hline $\mathrm{CV}$ & 6.30 & & 4.90 & & 3.40 & & 6.80 & \\
\hline
\end{tabular}

Note. *Means followed by the same letter, lower case in the column and upper case in the row, do not statistically differ for Tukey with $5 \%$ of probability.

The dry mass of the primary root (MR) and shoot (SDM) did not differ faced to the seed treatments (Table 2) used for both cultivars under conditions of absence of storage (Zero). Research has shown that the use of insecticide and bioregulator does not result in accumulation of dry matter in the seedlings (Dan et al., 2012; Moterle et al., 2011; Zimmer et al., 2016; Rigo et al., 2018). However, the cultivar Fepagro 37 RR reduced the dry mass of the primary root after storage of the seeds. According to Ludwig et al. (2011), the quality of the soybean seeds when stored and covered by polymers and insecticides do not result in differentiation regarding the accumulation of dry matter of the seedlings.

The shoot dry mass (SDM) of the cultivar Fepagro 37 RR in the absence of seed treatment and the seeds treated with Thimetoxan + polymers obtained superiority to the other treatments, in contrast, the cultivar NS6411 RR was not statistically different (Table 3). According to Dan et al. (2011), it is possible that there is no differentiation of biomass accumulation in the seedlings due to the seed treatment used. However, this character compared to storage times showed an increase in seedlings from seeds that were exposed to storage. This increase may be due to the consumption of the available energy in the cotyledons, when its accumulation is higher than the biomass production of the shoot and the primary root is increased (Henning et al., 2010, Nardino et al., 2016; Dellagostin et al., 2016; Vargas et al., 2018).

In relation to the enzymatic profiles, the isoenzymatic expression was differentiated for both cultivars and after storage of the seeds (Figure 1). Therefore, esterase expression (EST) evidenced two bands for the seedling shoot (SL) for Fepagro $37 \mathrm{RR}$ cultivar, being these more intense for the treatment with Thimetoxan + polymers, and micronutrients + polymer, in contrast, for the primary root (RL), the treatment with Thimetoxan + polymers showed only a band with higher intensity. In relation to the cultivar NS6411 RR the enzyme expressed higher intensity for the treatment with Thimetoxan + polymer in two bands, both in the aerial as well as radicular parts (Figure 1a). This enzyme acts on lipid metabolism reactions and esters hydrolysis (Peske et al., 2012), controlled deterioration (Padilha et al., 2001; Dubal et al., 2016), which culminate in the reduction of the physiological quality of the seeds.

Glutamate oxaloacetate transaminase (GOT) did not show intensity variation for both shoot (SL) and root (RL) bands for both cultivars (Figure 1b). The increase in metabolic activity may lead to deterioration due to the increase in the expression of the enzyme glutamate oxaloacetate transaminase, which is responsible for the oxidation of amino acids, reduction of $\alpha$-ketoglutarate for the synthesis of new amino acids, minimizing the energy supply for the Krebs cycle and to the developing embryo (Tunes et al., 2010; Strobel et al., 2016).

The expression of malate dehydrogenase (MDH) showed only one band for both cultivars (Figure 1c) in both shoot (SL) and root (RL). This enzyme acts on the cellular respiratory processes (Satters et al., 1994), catalyzes the malate and transforms it into oxaloacetate in the Krebs cycle, which results in the production of NADH, acts in the conversion of the stored triacylglycerols in the form of glucose and provides energy to the processes of germination and initial growth of the seedlings, in this way, when expressed, can minimize the seed vigor (Pedó et al., 2006). 

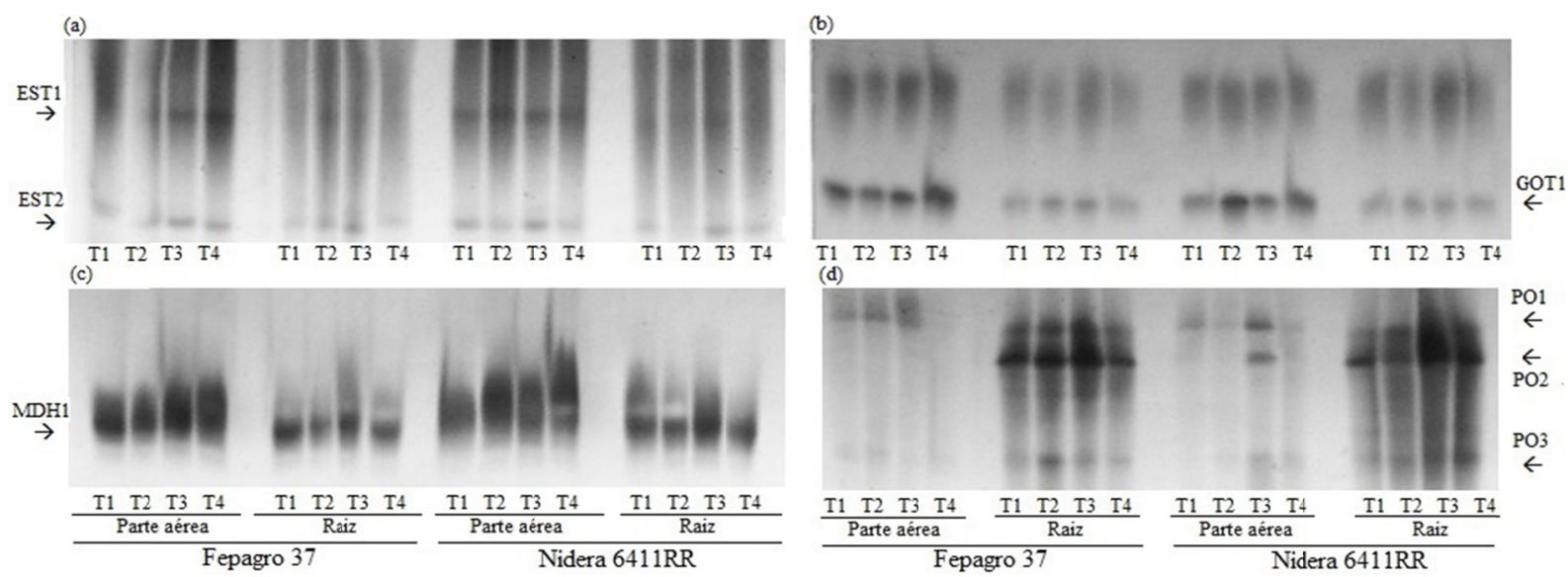

Figure 1. Isozyme expression of esterase (a), glutamate oxaloacetate transaminase (b), malate dehydrogenase (c) and peroxidase (d) for the primary root (RL) and shootlengths (SL) traits of seedlings from soybean cultivars

(Fepagro 37 RR and Nidera 6411 RR) submitted to different seed treatments

In relation to the peroxidase enzyme (PO), the aerial part of the soybean seedlings of the cultivar Fepagro 37 RR expressed only a low intensity band, referring to the treatment with micronutrients + polymers, in contrast, for the primary root, evidenced the formation of three bands of greater intensity. One of the bands referred to the treatment with Thimetoxan + micronutrient + polymer, however, for the NS6411 RR cultivar, in aerial part it was possible to visualize the formation of three bands with greater expression for the treatment with Thimetoxan + polymer (Figure 1d). This behavior did not allow differentiation among treatments for both cultivars. This isoenzyme can be used to evaluate the physiological potential of the seeds that are submitted to certain periods of storage (Costa et al., 2008), since current as polysaccharide binding, regulates cell elongation, scarring of pathogenic damage (Rossi \& Lima, 2001; Szareski et al., 2016b). The increase in its expression may be indicative of a reduction in the level of hydrogen peroxide (free radical) and its accumulation causes the lipid peroxidation, where it modifies the permeability of the cell membranes.

\section{Conclusions}

Addition of seed treatments influences the physiological performance of seedlings originated from soybean seeds stored for 240 days. The shoot and primary root lenghts, and shoot dry mass express the isoenzyme esterase through the aerial part and primary root of the seedling, the malate dehydrogenase is expressed in the primary root while in the peroxidase it is evident in the shoot of the seedlings.

\section{References}

Alfenas, A. C. (1998). Eletroforese de isoenzimas e proteínas afins: Fundamentos e aplicações em plantas e microrganismos (p. 574). Viçosa: UFV.

Almeida, A. S., Villela, F. A., Meneghello, G. E., Lauxem, L. R., \& Deuner, C. (2012). Desempenho fisiológico de sementes de aveia-preta tratadas com tiametoxam. Semina: Ciências Agrárias, 33(5), 1619-1628. https://doi.org/10.5433/1679-0359.2012v33n5p1619

Avelar, S. A. G., Baudet, L., Peske, S. T., Ludwig, M. P., Rigo, G. A., Crizel, R. L., \& Oliveira, S. (2011). Armazenamento de sementes de soja tratadas com fungicida, inseticida e micronutriente e recobertas com polímeros líquido e em pó. Ciência Rural, 41(10), 1719-1725. https://doi.org/10.1590/S0103-84782 011005000130

Bays, R., Baudet, L., Henning, A. A., \& Lucca, O. F. (2007). Recobrimento de sementes de soja com micronutrientes, fungicida e polímero. Revista Brasileira de Sementes, 29(2), 60-67.

Brasil. (2009). Ministério da Agricultura e Reforma Agrária. Regras para Análise de Sementes (p. 398). Brasília: SNAD/CLAV.

Carvalho, I. R., Souza, V. Q., Nardino, M., Follmann, D. N., Silva, A. D. B., ... Olivoto, T. (2015). Associações Fenotípicas entre Caracteres Fisiológicos da Soja Contrastante ao Hábito de Crescimento. Global Science and Technology, 8, 30-40. https://doi.org/10.14688/1984-3801/gst.v8n3p30-40 
CONAB. (2017). Acompanhamento da Safra Brasileira de Grãos. V. 4-SAFRA 2016/17-N. 6-Sexto levantamento. Brasília, Brazil.

Costa, C. J., Villela, F. A., Bertoncello, M. R., Tillmann, M. A. A., \& Menezes, N. L. (2008). Expressão de isoenzimas após a pré-hidratação de sementes de ervilha. Revista Brasileira de Sementes, 30(3), 130-138. https://doi.org/10.1590/S0101-31222008000300017

Dan, L. G. M., Dan, H. A., Barroso, A. L. L., \& Braccinir, A. L. (2010). Qualidade fisiológica de sementes de soja tratadas com inseticidas sob efeito do armazenamento. Revista Brasileira de Sementes, 32(2), 131-139. https://doi.org/10.1590/S0101-31222010000200016

Dan, L. G. M., Dan, H. A., Braccini, A. L., Albrecht, L. P., Ricci, T. T., \& Piccinin, G. G. (2011). Desempenho de sementes de soja tratadas com inseticidas e submetidas a diferentes períodos de armazenamento. Revista Brasileira de Ciências Agrárias, 6(2), 215-222. https://doi.org/10.5039/agraria.v6i2a939

Dan, L. G. M., Dan, H. A., Piccinin, G. G., Ricci, T. T., \& Ortiz, L. H. T. (2012). Tratamento de sementes com inseticida e a qualidade fisiológica de sementes de soja. Revista Caatinga, 25(1), 45-51.

Dellagostin, S. M., Bernardi, D., Nobrega, L. H. P., Dellagostin, D. M., Carvalho, I. V., Demari, G. H., ... Zimmer, P. D. (2016). Physiological parameters applied to the soybean seed storage techniques. International Journal of Current Research, 8, 41523-41527.

Dubal, I., Troyjack, C., Koch, F., Szareski, V. J., Pimentel, J. R., Nardino, M., ... Pedo, T. (2016). Effect of temperature on bean seed germination: vigor and isozyme expression. American Journal of Agricultural Research, 1, 0001-0009.

Ferrari, M., Nardino, M., Carvalho, I. R., Pelegrin, A. J., Belle, R., Szareski, V., ... Souza, V. Q. (2015). Hidroretentores: Alternativa para Maior Tolerância ao Déficit Hídrico na Cultura da Soja. Global Science and Technology, 8, 21-29. https://doi.org/10.14688/1984-3801/gst.v8n3p21-29

Ferrari, M., Pelegrin, A. J., Souza, V. Q., Nardino, M., \& Carvalho, I. R. (2014). Componentes de rendimento sob diferentes combinações de fungicidas e inseticidas em soja. Enciclopédia Biosfera, 10, 532-538.

Follmann, D. N., Souza, V. Q., Nardino, M., Carvalho I. R., \& Demari, G. (2014). Diferentes associações para aditivos em pré-semeadura na cultura da soja e seus efeitos sobre a qualidade das sementes. Enciclopédia Biosfera, 10, 1284-1292.

Follmann, D. N., Souza, V. Q., Nardino, M., Carvalho, I. R., \& Demari, G. H. (2014). Diferentes associações para aditivos em pré-semeadura na cultura da soja e seus efeitos sobre a qualidade das sementes produzidas. Enciclopédia Biosfera, 10(18), 1284-1292.

Gabriel, M., Muraro, D. S., Rosa, G. M., Wastowski, A. D., Kulczynski, S. M., Silva, J. C., Carvalho, I. R., ... Stumm, J. O. (2018). Chemical Control of Asian Soybean Rust and Its Effect in the Yield and Quality of Soybean Seeds. Journal of Agricultural Science, 10, 518-526. https://doi.org/10.5539/ jas.v10n10p518

Henning, F. A., Mertz, L. M., Jacob, E. A. J., Machado, R. D., Fiss, G., \& Zimmer, P. D. (2010). Composição química e mobilização de reservasem sementes de soja de alto e baixo vigor. Bragantia, 69(3), 727-734. https://doi.org/10.1590/S0006-87052010000300026

Karam, D., Magalhães, P. C., \& Padilha, L. (2007). Efeito da adição de polímeros na viabilidade, no vigor e na longevidade de sementes de milho (p. 5). Embrapa Milho e Sorgo.

Kavalco, S. A. F., Souza, V. Q., Follmann, D. N., Carvalho, I. R., Nardino, M., \& Demari, G. (2015). Desenvolvimento da soja com aplicações de hormônios em diferentes densidades de cultivo. Brasilian Jornal of Sustainable Agriculture, 4(1), 1-10.

Ludwig, M. P., Lucca Filho, O. A., Baudet, L., Dutra, L. M. C., Suemar, S. A. G., \& Crizel, R. L. (2011). Qualidade de sementes de soja armazenadas após recobrimento com aminoácido, polímero, fungicida e inseticida. Revista Brasileira de Sementes, 33(3), 395-406. https://doi.org/10.1590/S0101-31222011000300002

Ludwig, M. P., Oliveira, S., Avelar, S. A. G., Rosa, M. P., Lucca, O. A. L. F., \& Crizel, R. L. (2015). Armazenamento de sementes de soja tratadas e seu efeito no desempenho de plântulas. Tecnologia \& Ciência Agropecuária, 9(1), 51-56.

Malone, G., Zimmer, P. D., Meneghello, G. E., Castro, M. A., \& Peske, S. T. (2007). Expressão diferencial de isoenzimas durante o processo de germinação de sementes de arroz em grandes profundidades de semeadura. Revista Brasileira de Sementes, 29(1), 61-67. https://doi.org/10.1590/S0101-31222007000100009 
Meira, D., Carvalho, I. R., Nardino, M., Follmann, D. N., Pelegrin, A. J., Szareski, V. J., Ferrari, M., ... Souza, V. Q. (2016). Path analysis and dissimilarity in soybean with indeterminate habit. International Journal of Current Research, 8, 39568-39573.

Moterle, L. M., Santos, R. F., Scapim, C. A., Braccini, A. L., Bonato, C. M., \& Conrado, T. (2011). Efeito de biorregulador na germinação e no vigor de sementes de soja. Revista Ceres, 58(5), 651-660. https://doi.org/10.1590/S0034-737X2011000500017

Nardino, M., Carvalho, I. R., Demari, G. H., Pelissari, G., Pelegrin, A. J., Ferrari, M., ... Souza, V. Q. (2016). Components of variance, linear and canonical correlation soybean cultivars. Australian Journal of Basic and Applied Sciences, 10, 202-208.

Padilha, L., Vieiar, M. G. G. C., \& Von Pinho, E. V. R. (2001). Relação entre o teste de deterioração controlada e o desempenho de sementes de milho em diferentes condições de estresse. Revista Brasileira de Sementes, 23, 198-204. https://doi.org/10.17801/0101-3122/rbs.v23n1p198-204

Pelegrin, A. J., Carvalho, I. R., Nardino M., Ferrari, M., Szareski, V. J., Belle, R., ... Souza, V. Q. (2016). Performance of resistant soybean to asian rust in different environments in RS. International Journal of Current Research, 8, 38398-38401.

Pelegrin, A. J., Carvalho, I. R., Nardino, M., Ruwer, P. H., \& Souza, V. Q. (2016). Tiametoxam e chlorantraniliprole sobre a emergência e crescimento do cultivar Don Mario 7.0. Revista Sodebras, 11(126), 34-38.

Pereira, C. E., Oliveira, J. A., \& Evangelista, J. R. E. (2005). Qualidade fisiológica de sementes de milho tratadas associadas a polímeros durante o armazenamento. Ciência e Agrotecnologia, 29(6), 1201-1208. https://doi.org/10.1590/S1413-70542005000600014

Peske, S. T., Villela, F. A., \& Meneghello, G. E. (2012). Sementes: Fundamentos Cientificos e Tecnológicos (3rd ed., p. 573). Pelotas: UFPel.

Piccinin, G. G., Braccini, A. L., de Morais Dan, L. G., Bazo, G. L., \& da Silva Lima, L. H. (2013). Influência do armazenamento na qualidade fisiológica de sementes de soja tratadas com inseticidas Ambiência, 9(2), 289-298.

Rigo, G. A., Schuch, L. O. B., Vargas, R. L., Barros, W. S., Szareski, V. J., Carvalho, I. R., ... Pedo, T. (2018). Micronutrient Content and Physiological Quality of Soybean Seeds. Journal of Agricultural Science, 10(4), 223-230. https://doi.org/10.5539/jas.v10n4p223

Rossi, C., \& Lima, G. P. P. (2001). Cádmio e a atividade de peroxidase durante a germinação de sementes de feijoeiro. Scientia Agricola, 58(1), 197-199. https://doi.org/10.1590/S0103-90162001000100030

Scandálios, J. G. (1969). Genetic control of multiple molecular forms of enzymes in plants: A rewiew. Biochemical Genetics, 3(1), 37-79. https://doi.org/10.1007/BF00485973

Shatters, R. G., Abdelghany, A., Elbagoury, O., \& West, S. H. (1994). Soybean seed deterioration and response to priming: changes in specific enzyme activities in extracts from dry and germinating seeds. Seed Science, 4, $33-41$.

Souza, V. Q., Follmann, D. N., Nardino, M., Baretta, D., Carvalho, I. R., Caron, B. O., .. Demari, G. H. (2015). Produção de Sementes de Soja e Vigor das Sementes Produzidas com Diferentes Tratamentos de Sementes. Global Science and Technology, 8, 157-166. https://doi.org/10.14688/1984-3801/gst.v8n1p157-166

Strobel, T., Koch, F., Aisenberg, G. R., Szareski, V. J., Carvalho, I. R.., \& Aumonde, T. Z. (2016). Physical and physiological quality of soybean seeds harvested under different trial systems after storage period. Australian Journal of Basic and Applied Sciences, 10, 124-130.

Szareski, V. J., Carvalho, I. R., Kehl, K., Levien, A. M., Rosa, T. C., Barbosa, M. H., Demari, G. H., ... Aumonde, T. Z. (2018). Phenotypic and predicted genetic approaches for genotype ranking of wheat seed yield in Brazil. Genetics and Molecular Research, 17, 1-13. https://doi.org/10.4238/gmr18026

Szareski, V. J., Carvalho, I. R., Nardino, M., Demari, G. H., Bahry, C. A., \& Aumonde, T. Z. (2016). Phenotype stability of soybean genotypes for characters related to the physiological quality of seed produced under different environmental conditions. Australian Journal of Basic and Applied Sciences, 10(15), 279-289.

Szareski, V. J., Carvalho, I. R., Nardino, M., Pelegrin, A. J., Ferrari, M., Gaviraghi, R., ... Souza, V. Q. (2016). Competition of soybean genotypes cultivated in lowlands of Rio Grande do Sul, Brazil. International Journal of Current Research, 8, 39714-39718. 
Szareski, V. J., Zanatta, E., Koch, F., Aisenberg, G. R., Demari, G. H., Kehl, K., ... Aumonde, T. Z. (2016). Pre-harvest desiccation and seed production in soybean crops. International Journal of Current Research, 8 , 41534-41537.

Tunes, L. M., Pedroso, D. C., Meneghello, G. E., Castro, M. A. S., Barros, A. C. S. A., Badinelli, P. G., \& Muniz, M. F. B. (2010). Perfil enzimático em sementes de cevada em resposta a diferentes concentracões salinas. Interciência, 35(5), 369-373.

Vargas, R. L., Shuch, L. O. B., Barros, W. S., Rigo, G. A., Szareski, V. J., Carvalho, I. R., Pimentel, J. R., Troyjack, C., Souza, V. Q., Rosa, T. C., Aumonde, T. Z., Pedo, T. (2018). Macronutrients and Micronutrients Variability in Soybean Seeds. Journal of Agricultural Science, 10(4), $209-222$. https://doi.org/10.5539/jas.v10n4p209

Vidor, C., \& Peres, J. R. R. (1988). Nutrição das plantas com molibdênio e cobalto. Enxofre e micronutrientes na agricultura brasileira (pp. 197-204). Londrina: Embrapa-CNPSo/SBCS.

Zanatta, E., Szareski, V. J., Carvalho, I. R., Pimentel, J. R., Troyjack, C., Dellagostin, S. M., ... Aumonde, T. Z. (2018). Pre-harvest Desiccation: Productivity and Physical and Physiological Inferences on Soybean Seeds During Storage. Journal of Agricultural Science, 10(6), 354-362. https://doi.org/10.5539/jas.v10n6p354

Zimmer, G., Koch, F., Carvalho, I. R., Szareski, V. J., Demari, G., \& Pedo, T. (2016). Seed quality and initial performance of seedlings of soybean produced off-season in rio grande do sul, brazil. International Journal of Current Research, 8, 40325-40329.

\section{Copyrights}

Copyright for this article is retained by the author(s), with first publication rights granted to the journal.

This is an open-access article distributed under the terms and conditions of the Creative Commons Attribution license (http://creativecommons.org/licenses/by/4.0/). 